\title{
大型係留船の固有周期と減衰特性に関する一考察
}

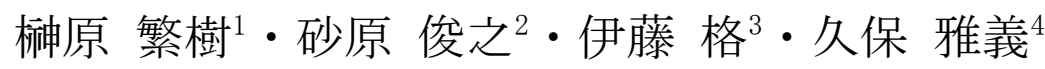

\section{One Consideration to Characteristics on Natural Period and Damping Effect of a Moored Large Bulk Carrier}

\author{
Shigeki SAKAKIBARA, Shunji SUNAHARA, Kaku ITO \\ and Masayoshi KUBO
}

\begin{abstract}
In our previous study, investigations on property of ship motions was conducted through a numerical simulation and a field observation of ship motions and mooring loads. From the investigations, it was concluded that low-frequency motions such as sway, surge and yaw were induced significantly by resonant effects with the long-period wave, and resonant roll motion also occurred at the berth due to the swell component of the wave. It is important for the investigations on property of the ship motions to estimate the natural periods of each ship motion and damping effects precisely as possible. In this study, we have conducted a physical model test on free oscillations of the model ship for a large vessel moored along dolphin to obtain the property of the natural periods and the damping effects.
\end{abstract}

Keywords: Ship mooring, Ship motion, Free oscillation, Natural period, Damping effect キーワード：港湾・倸留，船体運動，自由振動，固有周期，減衰特性

\section{1. 緒言}

係留船の固有周期は、船体の質量または慣性モー メントと復原力係数から算出されるが、船体自身が 復原力を持つHeave、Pitch およびRol1 と、係留索 および防舷材による係留力に基づくSway、Surge お よび Yaw からなる ${ }^{(1)}$ 。ここに質量（慣性モーメント） は運動モードごとに付加質量 (付加慣性モーメント) を浅水影響下で予め求めておく必要があり、また係 留索の初期張力を考慮して係留索と防舷材の変位復 原力特性からバネ定数を適切に算定する必要がある。

一方長周期波来襲時の船体運動を推算するに際 して、Sway、Surge および Yaw の長周期船体運動に おける固有周期と減衰特性を精度よく評価すること が重要である ${ }^{(2)}(3)$ 。岸壁前面における係留船の減衰
係数は、ポテンシャル論から求められる造波減衰力 とそれ以外の係留索のヒステリシスロスや非線形流 体力に起因寸る粘性減衰力により構成されるものと 考えられる。係留船の減衰特性に関寸る研究は、模 型実験による既往の研究として、久保ら ${ }^{(4)}$ や白石ら ${ }^{(5)}$ は、実際の係留索と防舷材の非対称係留状況では ないが、対称係留時で検討を行っている。また実船 による検討では、漁船や小型船による現地実験によ る検討 ${ }^{(6)}$ (7)や、波浪中の大型船の船体動摇計測結果 に対する再現計算を通じて、ポテンシャル論による 減衰係数以外の減衰係数を算出寸る検討が行われて いるのみである(8)。

そこで本研究では、大型係留船の固有周期および 減衰特性に関して、実際の大型船の係留状況を設定

\footnotetext{
正会員 東海大学 海洋学部

非会員 東海大学 海洋学部

正会員 株式会社日本海洋科学

正会員 神戸大学名誉教授
}

( 个424-8610

( Т424-8610

(干212-0013

( (658-0022
静岡県静岡市清水区折戸 3-20-1)

静岡県静岡市清水区折戸 3-20-1)

神奈川県川崎市幸区堀川町 580)

神戸市東灘区深江南町 5-1-1) 
Table 1 Ship dimensions (Proto/ Model)

\begin{tabular}{ll|c|c}
\hline \multirow{2}{*}{} & & \multicolumn{2}{|c}{ Ship dimensions } \\
\cline { 3 - 4 } & Proto ship & Model ship \\
\hline 全長 & LoA & $289.5 \mathrm{~m}$ & - \\
\hline 重線間長 & Lpp & $277.0 \mathrm{~m}$ & $99.0 \mathrm{~cm}$ \\
\hline 幅 & $\mathrm{B}$ & $49.0 \mathrm{~m}$ & $49.0 \mathrm{~cm}$ \\
\hline 深さ & $\mathrm{D}$ & $27.0 \mathrm{~m}$ & $27.0 \mathrm{~cm}$ \\
\hline 喫水 & $\mathrm{d}$ & $9.43 \mathrm{~m}$ & $9.4 \mathrm{~cm}$ \\
\hline 質量 & $\mathrm{M}$ & $83,643 \mathrm{t}$ & $45.745 \mathrm{~kg}$ \\
\hline 重心高さ & $\mathrm{KG}$ & $13.24 \mathrm{~m}$ & $13.2 \mathrm{~cm}$ \\
\hline 慣動半径 & $\mathrm{k}_{\mathrm{yy}}$ & $15.2 \mathrm{~m}$ & $15.2 \mathrm{~cm}$ \\
\hline 横メ夕セター & $\mathrm{GM}$ & $13.21 \mathrm{~m}$ & $12.7 \mathrm{~cm}$ \\
\hline 水深 & $\mathrm{h}$ & $14.0 \mathrm{~m}$ & $14.0 \mathrm{~cm}$ \\
\hline
\end{tabular}

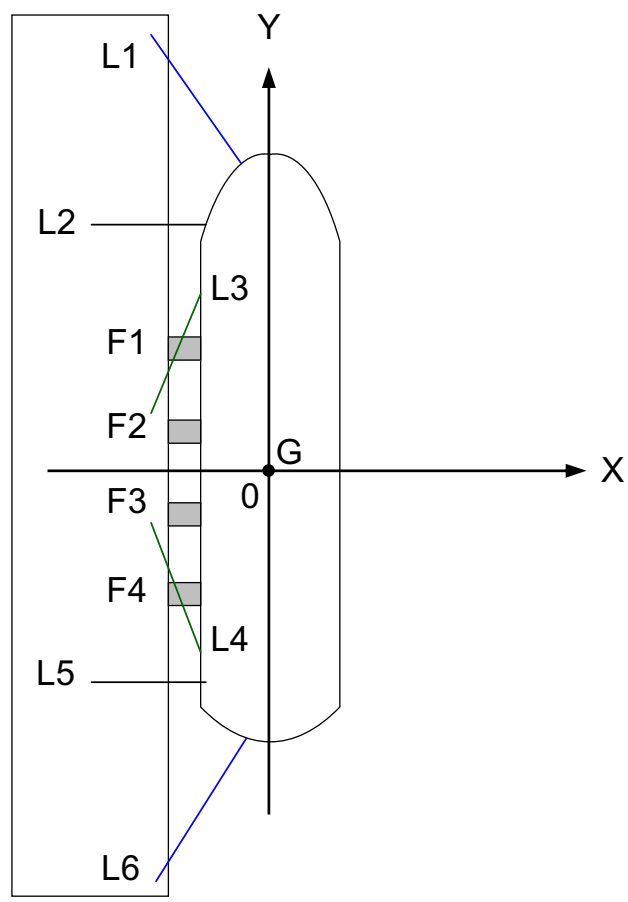

Fig.1 Mooring arrangement of the proto ship

した模型船を用いた自由振動実験を行なった。合わ せて数值計算による当該自由振動実験の再現を通じ て、固有周期および減衰特性への係留索の初期張力 および防舷材の特性の影響について検討した。

\section{2. 実験方法}

\section{1 実船の船体諸元および係留図}

\subsection{1 船体諸元}

対象船舶は大型バルク船とし、船体諸元を Table 1 に示す。ここに船体コンディションはバラスト状態 とした。

\subsection{2 係留図}

Fig. 1 に当該大型船の係留状況を示す。係留索は ヘッドライン(L1)、フォア・ブレストライン(L2)、

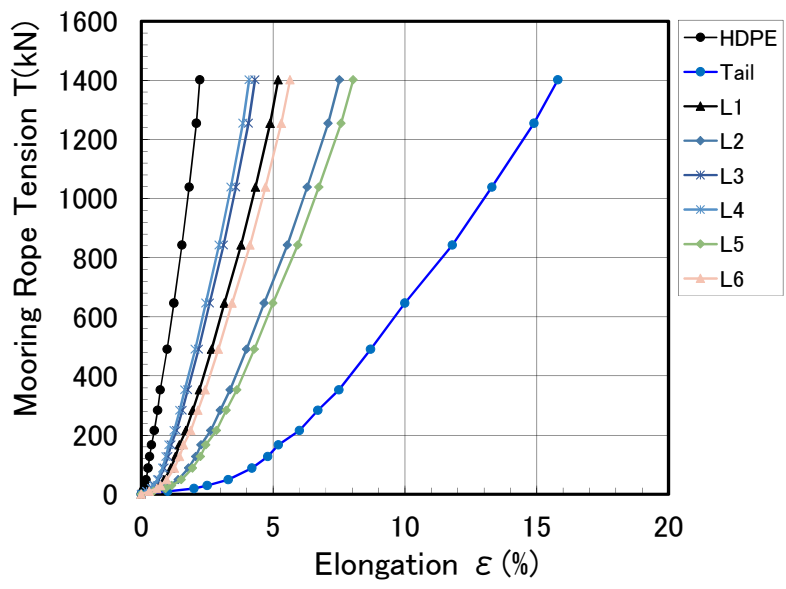

Fig.2 Mooring line property of the proto ship

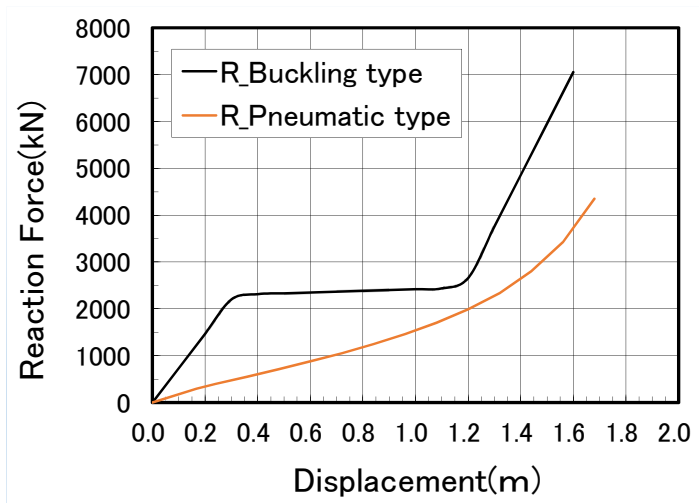

Fig.3 Reaction force property of the proto fender

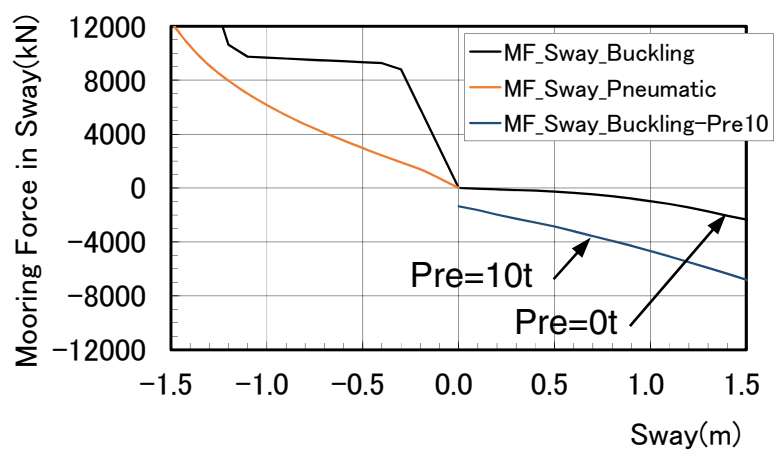

Fig.4 Mooring force property in sway of the proto ship

フォア・スプリングライン (L3)、アフト・スプリン グライン (L4)、アフト・ブレストライン (L5) および スタンライン (L6)が 16〜18 本配置されることが一 般的であり、各索の張力特性は Fig. 2 に示す $\phi 44 \mathrm{~mm}$ の高張力化繊ロープ（ $\phi 100 \mathrm{~mm}$ ナイロンテイルロー プ付き）とし、初期張力は各索に一律 $10 t(98 \mathrm{kN})$ 与 えられるものとした。防舷材はFig. 3 に示す反力特 性を持つ高さ $2250 \mathrm{~mm}$ の定反力型防舷材が 4 基設置さ れるものとした (Fig. 1 の F1〜F4)。なお当該防舷材 の反力特性は、圧縮率約 $15 \%$ で一定の反力となり、 規定圧縮率 $52.5 \%$ (圧縮量 $1.18 \mathrm{~m}$ ) を超えると急激に 
上昇する特性を持つFig. 4 には係留索および防舷 材を合わせた当該大型船の Sway 方向係留力を示す。

\section{2 模型船の船体諸元、実験配置および係留 図}

\section{2.1 船体諸元}

模型船は縮尺 $S=1 / 100$ の模型とし、模型船の船体 諸元はTable 1 に併記している。なお模型船の船体 諸元において、慣動半径および重心高さについては 実船に合わせたが、横メタセンターは二次元模型船 (矩形船)のため、若干異なるが概ね一致している。

\subsection{2 模型実赜の四置および係留図}

模型実験では長さ $38 \mathrm{~m} \times$ 幅 $1 \mathrm{~m}$ の東海大学海洋学部 所有の二次元水槽を用い、水深は $14 \mathrm{~cm}$ と一定とした。

Fig. 5 に模型船の係留状況および計測装置の配置 を示す。船体運動は 3D トラッカーシステムで 6 モー ドの船体運動を計測した ${ }^{(9)}$ 。

模型係留索および防舷材のバネ定数は、Fig. 4 に 示したSway 方向係留力を参照して、フルード則に基 づき設定した。ここに実スケールでの係留索および 防舷材のバネ定数はそれぞれ $K L=2775 \mathrm{kN} / \mathrm{m}$ および $K F s=29329 \mathrm{kN} / \mathrm{m}$ であり、断面模型船の三次元模型 船に対寸る質量分担率 (0.542) から係留索と防舷材 のバネ定数を設定し、係留索および防舷材はそれぞ れ 2 基として係留索の 1 本当りバネ定数 $\mathrm{kl}=75 \mathrm{~N} / \mathrm{m}$ および防舷材の 1 基当りバネ定数 $k f s=794 \mathrm{~N} / \mathrm{m}$ と設 定した。また初期張力は実船で各索 $10 t(98 \mathrm{kN})$ を与 える場合として 1 本当たり $0.7 \mathrm{~N}$ と設定した。模型係 留索のバネ部自由長は約 $130 \mathrm{~mm}$ 、防舷材は高さ $30 \mathrm{~mm}$ とした。

また係留索の初期張力がゼロの場合、係留索バネ 定数が変化するため、Fig. 4 に示した Sway 方向係留 力特性から別途設定し、 1 本当り $k l_{0}=13 \mathrm{~N} / \mathrm{m}$ とした。 合わせて防舷材の反力特性による船体動摇への影響 を検証するため、Fig. 4 に追記した吸収エネルギー 性能が同等の反力漸増型防舷材を選定し、模型バネ 定数を 1 基当り $k f a=192 \mathrm{~N} / \mathrm{m}$ と設定した。

\section{2.3 実験条件}

自由振動実験はSway およびRo11について実施し、 静水中、当該模型船を人力でゆっくり毫引して Sway またはRo11 に初期変位を与えることで行った。Sway 自由振動実験では、初期張力がある場合とゼロの場 合について行い、防舷材が定反力型と空気式の場合
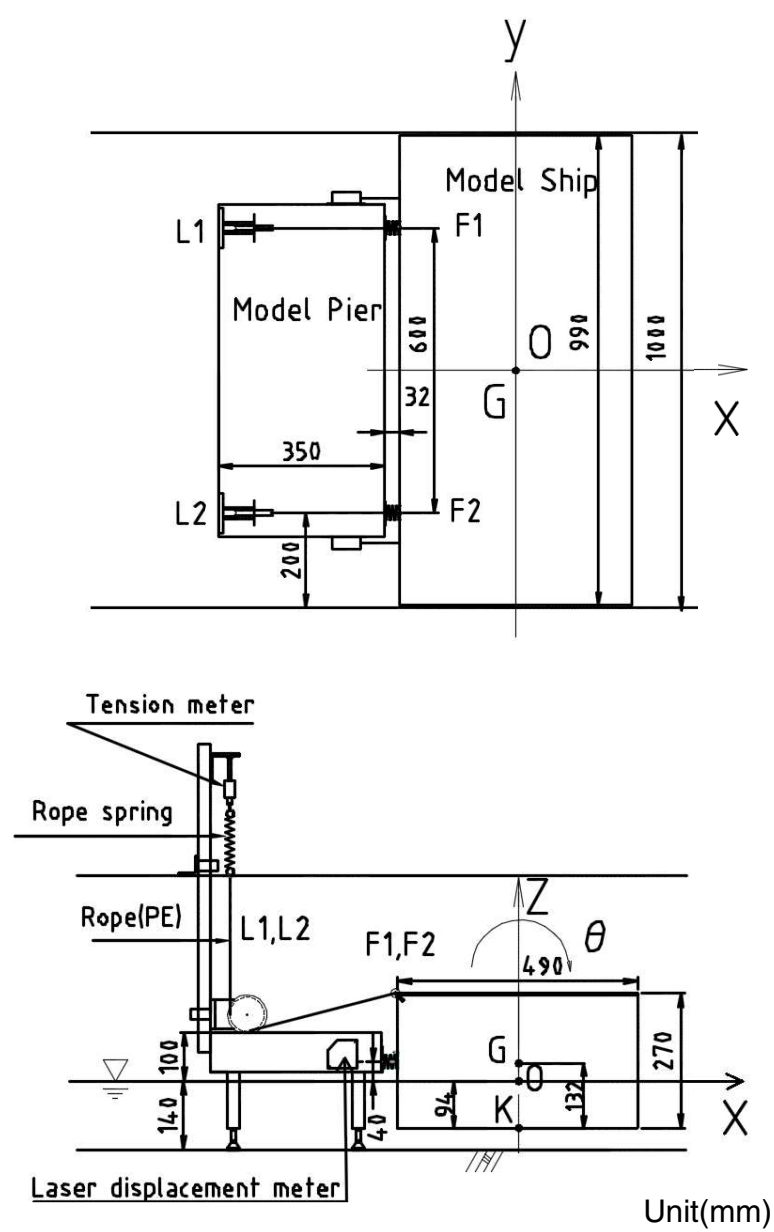

Fig.5 Model ship mooring condition and layout of measuring equipment

でそれぞれ実施した。Rol1 自由振動実験では、係留 索バネ定数と復原力係数 $\left(G M_{T}\right)$ の大きさの違いおよ び船体重心高さと防舷材取付け高さの関係から、 Ro11 の固有周期や減衰特性に関しては係留索や防 舷材による係留力の影響は少ないと考え、無係留状 態で行なった。

\section{3. 実験結果および考察}

\subsection{Roll 自由振動}

\subsection{1 自由振動の時系列結果}

本実験では係留中の船体動摇を想定しているた め、初期角度をゼロとした状態からゆっくり所定の 初期角度となるように人力で模型船の Rol1 角を調 整する方法を取っている。また、浅水中での実験で あったため、非線形性を確認するための Ro11 角度を 設定すると水底に接触してしまうため、ここでは船 体が水底に接触しない程度の最大值として約 $6^{\circ}$ の 初期角度とした。Fig. 6 にRo11 の自由振動実験結果 を示す。 


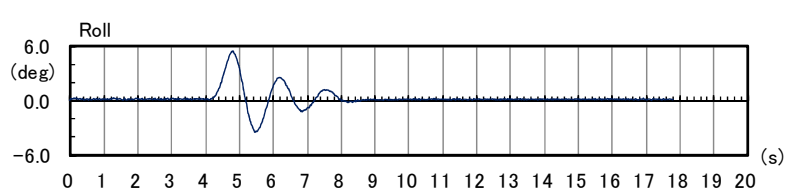

Fig.6 Experimental result on time series of free oscillation in roll of the model ship

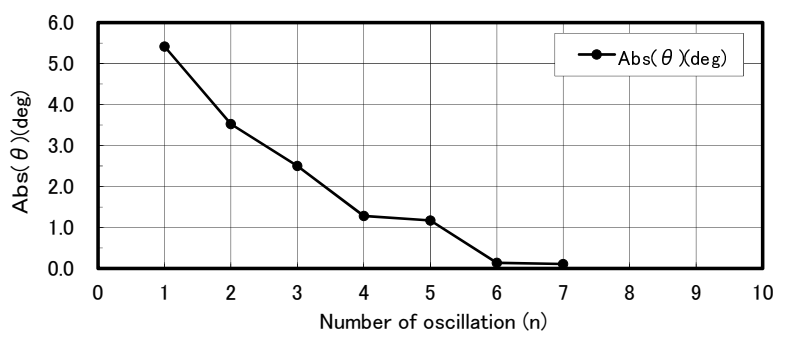

(a) Curve of damping

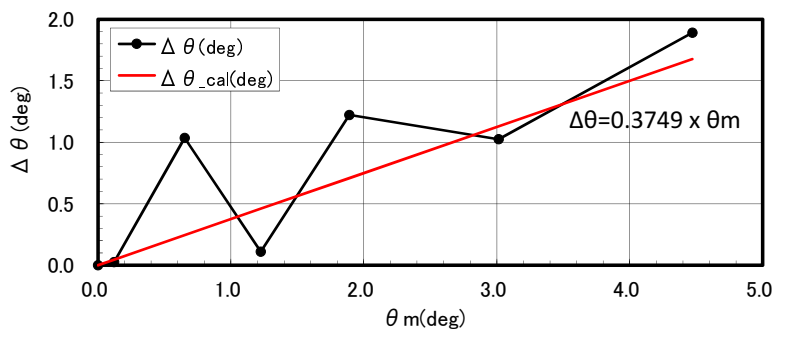

(b) Curve of extinction

Fig.7 Experimental result on curves of damping and extinction in roll of the model ship

\subsection{2 減滅係数および固有周期の算出}

(1) 減衰角曲線、減滅曲線および減滅係数

Fig. 6 の Rol1 自由振動時系列結果より、減衰角曲 線および減滅曲線を Fig. 7 にまとめる。ここに減衰 角曲線では 7 つ摇数を抽出し、減滅曲線は相隣る 二つの振幅に関する式(1)を用いて算出した ${ }^{(10)}$ 。

$$
\begin{aligned}
& \Delta \theta=A b s\left(\theta_{n}\right)-A b s\left(\theta_{n+1}\right) \\
& \theta_{m}=0.5 \times\left(\operatorname{Abs}\left(\theta_{n}\right)+\operatorname{Abs}\left(\theta_{n+1}\right)\right)
\end{aligned}
$$

そして当該減滅曲線の線形近似式の一次係数と して減滅係数を 0.3749 と算出した。ここに算出され た減滅係数は、ポテンシャル論から求められる造波 減衰力とそれ以外の係留索のヒステリシスロスや非 線形流体力に起因する粘性減衰力により構成される 係数の全てを含む減滅係数となる。

(2) 固有周期

上述の減衰角曲線算出において、Fig. 6 の Rol1 自 由振動時系列結果より 7 つの摇数を抽出した。この

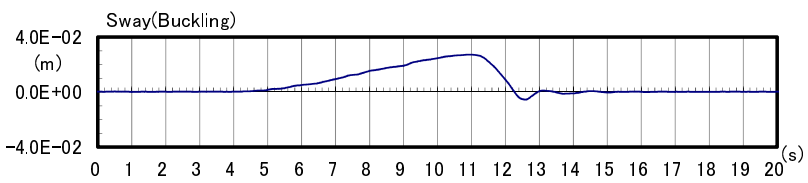

(a) with pretension

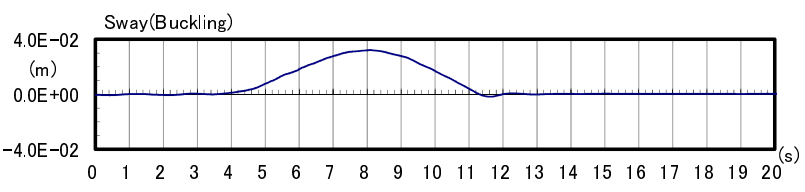

(b) without pretension

Fig.8 Experimental results on time series of free oscillation in sway with/without pretension in buckling type fender usage

内一周期分の 5 つの振動を平均して、平均 Rol1 固有 周期として $1.36 \mathrm{~s}$ を算出した。

\subsection{Sway 自由振動への初期張カと防舷材仕様 の影蔡 \\ 3.2.1 初期張力の影踾}

(1) 自由振動の時系列結果

Sway 自由振動実験では、模型船の両舷上部を人力 で支持して、ゆっくりと防舷材から離す方向（正方 向）にSway 変位を与えた。そして急激にその人力を 解放することで行なった。Fig. 8 にSwayの自由振動 実験結果を示す。Fig. 8 には初期張力ありの場合と ゼロの場合を併記している。初期張力ありの場合、 Sway の初期変位解放後、係留索の張力により船体は 急速に防舷材側に引き戻されている様子がわかる。 一方初期張力ゼロの場合、初期変位解放後、緩やか にSway 船体運動が始まり、初期張力ありの場合に較 べ、防舷材に接触するまでに時間を要している様子 がわかる。また船体は防舷材に接触後、防舷材を圧 縮して再び沖側へ離れるが、微小な変位で繰り返し はほとんどないことが確認された。

(2) 歪エネルギーから船体運動および造波減衰力 などへのエネルギー散逸について

当該 Sway 自由振動においては、初期変位に対応 した係留索張力により Sway 運動を与えていた。ここ に Sway 自由振動におけるエネルギーの移動の状況 を Fig. 9 にまとめる。まず係留索の歪エネルギー $\left(E_{L}\right)$ は船体の運動エネルギー $\left(E_{S}\right)$ に変換され、船体 が防舷材に衝突し圧縮変形時には防舷材の歪エネル ギー（吸収エネルギー）（E $\left.E_{f}\right)$ に変換される。この間 船体運動に伴い造波減衰力や粘性減衰力など $\left(E_{d v}\right)$ 


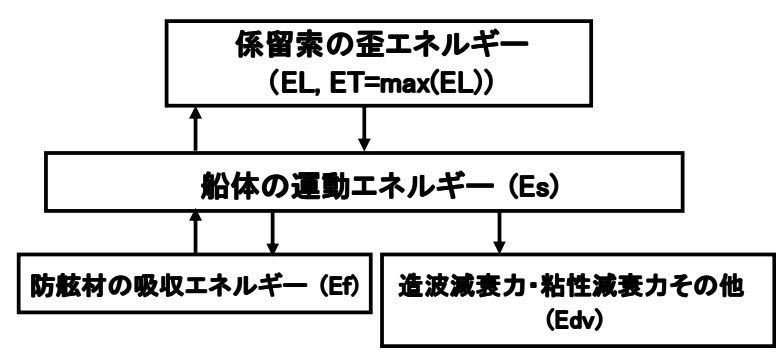

Fig.9 Energy transform during the free oscillation in sway of the model ship

にエネルギーは散冕される。Fig. 10 に係留索および 防舷材の係留力および吸収エネルギ一特性を示すが、 式 (2)〜（4)にそれぞれのエネルギ一算出式を示す。

$$
\begin{aligned}
& E_{L}=0.5 \cdot k_{l} \cdot \Delta x_{l}^{2} \times n_{l} 、 \\
& E_{f}=0.5 \cdot k_{f} \cdot \Delta x_{f}{ }^{2} \times n_{f} \\
& E_{s}=0.5 \cdot\left(M+m_{11}(\infty)\right) \cdot v_{x}{ }^{2} \\
& E T=\max \cdot\left(E_{L}\right) \\
& E_{d v}=E T-\left(E_{L}+E_{s}+E_{f}\right)
\end{aligned}
$$

ここに $E_{L} 、 E_{f} 、 E_{S}$ E ETおよび $E_{d v}$ は、係留索で蓄えら れた歪エネルギー、防舷材で蓄えられた歪エネルギ 一、船体の運動エネルギー、総エネルギーであり係 留索で蓄えられた歪エネルギー最大值、および最終 的には総エネルギーET に等しくなる造波減衰力や 粘性減衰力などとして散逸するエネルギーである。 また $k_{1} 、 k_{f} 、 \Delta x_{1} 、 \Delta x_{f}$ および $n_{1} 、 n_{f}$ は、係留索ま たは防舷材のバネ定数、変形量および個数であり、M、 $m_{11}(\infty)$ は船体質量および Sway の不変付加質量、 $V_{X}$ はSway 運動速度である。以上のような諸量の定義に 基づき、Sway 自由振動におけるエネルギー移動およ び散逸における係留索の初期張力による影響を調べ てみた。

Sway 変位量、変位速度、そして式 $(2) （ 4)$ に示し た係留索に蓄積された歪エネルギーまたは防舷材吸 収エネルギーおよび船体の運動エネルギーの時系列 結果をFig. 11 に示し、要約を Table 2 にまとめる。

初期張力ありの場合、係留索に蓄積された総歪工 ネルギーの約 6 割が船舶の接岸エネルギー（船体の 接岸方向速度が最大 $\left(V_{b}\right)$ となるときの運動エネルギ 一）として使用され、またその接岸エネルギーの約 7 割が防舷材に吸収されていることがわかる。また

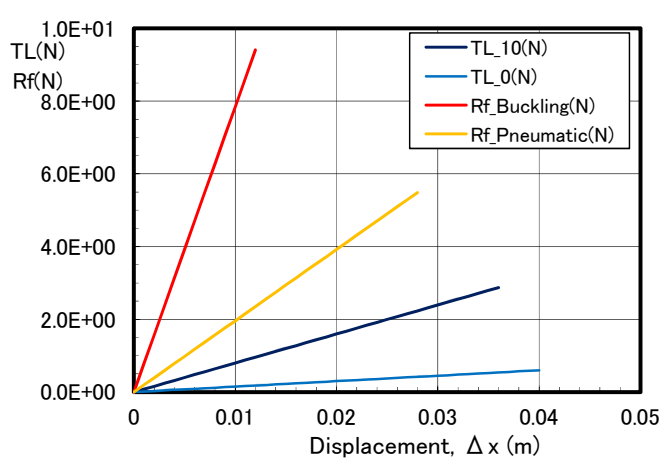

(a) Mooring force (per unit)

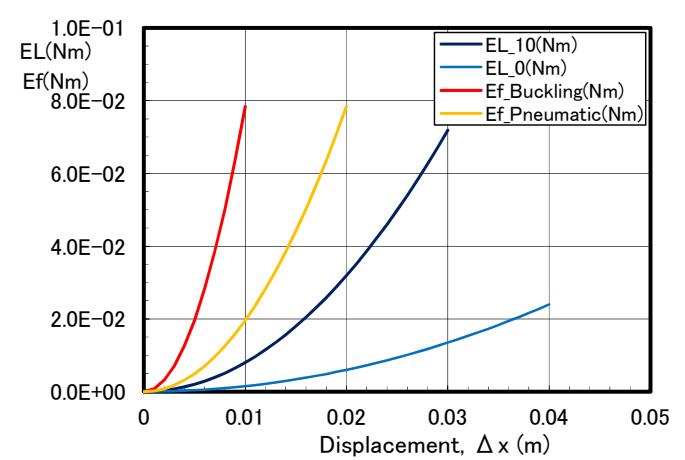

(b) Strain energy and energy absorption (per 2pcs.)

Fig.10 Characteristics on mooring force and energy absorption of the mooring line with/without pretension and two kinds of fenders

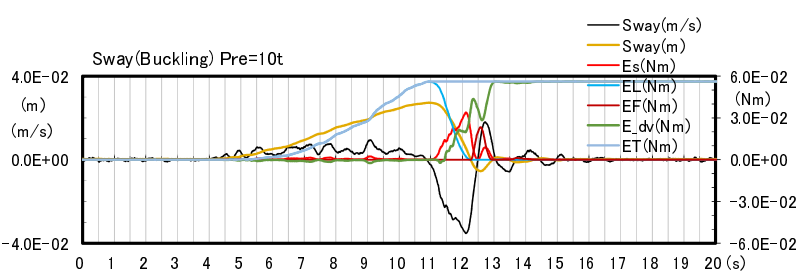

(a) with pretension

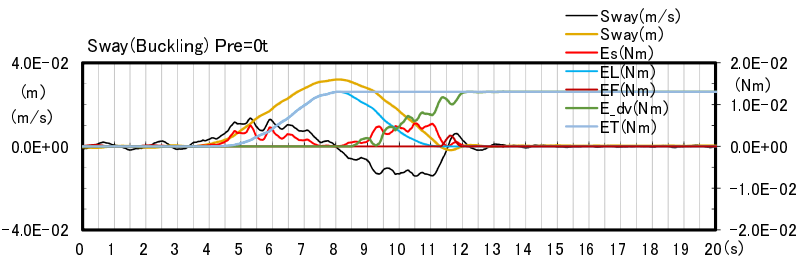

(b) without pretension

Fig.11 Experimental results on time series of free oscillation and energy transform in sway with/without pretension in buckling type fender usage

防舷材から反発した時の Sway 速度最大值 $\left(V_{u b}\right)$ は接 岸速度 $\left(V_{b}\right)$ に対して約 5 割である。 
Table 2 Ratio of energy transform and velocity at berthing and unberthing for each pretension and fender

\begin{tabular}{c|c|c|c|c}
\multicolumn{5}{c}{ type } \\
\hline Fender & Pretension & max.(Es)/ET & max.(Ef)/Es & $\mathrm{V}_{\mathrm{ub}} / \mathrm{V}_{\mathrm{b}}$ \\
\hline \multirow{2}{*}{ Buckling } & $10 \mathrm{t}$ & 0.604 & 0.688 & 0.513 \\
\cline { 2 - 5 } & $0 \mathrm{t}$ & 0.420 & 0.469 & 0.437 \\
\hline Pneumatic & $10 \mathrm{t}$ & 0.507 & 0.512 & 0.434 \\
\hline
\end{tabular}

一方初期張力ゼロの場合、係留索に蓄積された総 歪エネルギーの約 4 割が船舶の接岸エネルギーに使 用され、接岸エネルギーの内約 5 割が防舷材に吸収 されることがわかった。また防舷材から反発した時 のSway 速度は接岸速度に対して約 4 割となった。

以上より、船舶の接岸エネルギー $\left(E_{S}\right)$ は、初期張 力ありの場合（硬い係留索による場合）の方が初期 張力ゼロの場合（柔らかい係留索による場合）に較 べ、比較的大きな割合で防舷材に吸収されることが わかった。合わせて、船体が防舷材と接触している 時間は両者 $0.6 \mathrm{~s}$ でほぼ同じであつたが、船舶の接岸 エネルギーが最大值を生じてから船体が防舷材に接 触し、さらに防舷材の吸収エネルギーが最大值を生 じるまでの時間は両者で大きく異なり、初期張力ゼ 口の場合 $1.1 \mathrm{~s}$ に対して、初期張力ありの場合 $0.5 \mathrm{~s}$ と短くなっていたことがわかった。このことから初 期張力ありの場合、エネルギーの散逸を十分に行な えず、防舷材の負担するエネルギ一吸収割合が大き くなったものと考えられる。また初期張力ありの場 合、係留索に蓄積された総歪エネルギー $\left(E_{T}\right)$ が船舶 の接岸エネルギー $\left(E_{s}\right)$ に移行する割合が大きくなっ ていたが、これはSway 初期変位が $0.027 \mathrm{~m}$ と $0.032 \mathrm{~m}$ と初期張力ありの場合の方が若干小さかったことに も影響していると考えられる。

\subsection{2 防舷材仕様の影響}

(1) 自由振動の時系列結果

初期張力がある場合において、防舷材を空気式 (柔らかいバネ) に変更した場合のSway 変位量、速 度、そして式(2)〜 (4) に示した係留索に蓄積された 歪エネルギーまたは防舷材の吸収エネルギ一、およ び船体の運動エネルギーの時系列結果を Fig. 12 に 示す。Fig. 8(a) の定反力型防舷材を用いる場合の Sway 自由振動実験結果と比較して、防舷材の圧縮変 位が大きく、かつ防舷材への接岸後に生じる船体の 沖側への戻りがゆっくりとなることが確認された。

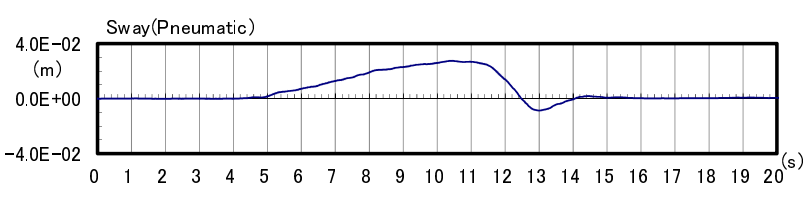

(a) Free oscillation

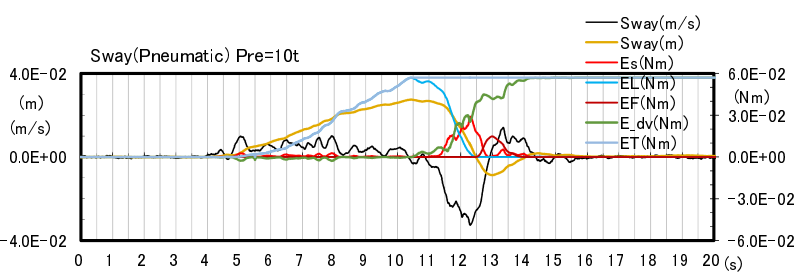

(b) Energy transform

Fig.12 Experimental results on time series of free oscillation and energy transform in sway with pretension in pneumatic type fender usage

(2) 歪エネルギーから船体運動および造波減衰力 などへのエネルギーの散逸について

Table 2 にも併記しているが、係留索に蓄積され た総歪エネルギーの約 5 割が船体の接岸エネルギー に使用され、その接岸エネルギーの約 5 割が防舷材 に吸収されていることがわかる。また防舷材から反 発した時の Sway 速度 $\left(V_{u b}\right)$ は接岸速度 $\left(V_{b}\right)$ に対して 約 4 割である。

以上より、Sway 初期変位が定反力型防舷材と空気 式防舷材の場合で $0.027 \mathrm{~m}$ と $0.028 \mathrm{~m}$ とほぼ同じであ ることから、係留索に蓄積された総歪エネルギー $\left(E_{T}\right)$ は同等であるが、船舶の接岸速度は $0.035 \mathrm{~m} / \mathrm{s}$ と $0.033 \mathrm{~m} / \mathrm{s}$ と若干違いがみられ、これに伴い接岸エネ ルギーに違いがみられた。これはSway 初期変位解放 のタイミングが両者で異なり、空気式の方が緩やか に解放していたことが原因と考えられる。一方防舷 材が負担する接岸エネルギーの割合については、定 反力型防舷材の場合に較べ空気式防舷材の場合の方 が低減されていた。これは船体が防舷材と接触して いる時間がそれぞれ 0.6s と $1.6 \mathrm{~s}$ と空気式防舷材の 方が大幅に長く、エネルギーの散逸を十分に行なえ ることが起因しているものと考えられる。

\subsection{Roll および Sway 自由振動の再現 3.3.1 船体の運動方程式}

Fig. 6 およびFig. 8 に示した Rol1 および Sway の 模型船の自由振動実験結果について数值計算による 再現を試みる。これを通じて減衰特性について検討 を行う。 
当該模型船の自由振動時の船体挙動再現に際し ては、式(5)〜 (8) の運動方程式を解くことで船体運 動の変位量および係留力を算定するものとする。

$\sum_{j=1}^{6}\left\{M_{i j}+m_{i j}(\infty)\right\} \cdot \ddot{x}_{j}(t)+\sum_{j=1-\infty}^{6} \int_{j}^{t} \dot{x}_{j}(\tau) \cdot L_{i j}(t-\tau) d \tau+\sum_{j=1}^{6} D_{i j} \cdot \dot{x}_{j}(t)$

$+\sum_{j=1}^{6} C_{i j} \cdot x_{j}(t)+G_{i}=F_{i}(t),(i=1,2, \ldots \ldots, 6)$

$F_{i}(t)=F_{e i}+F_{w i},(i=1,2, \ldots \ldots, 6)$

$m_{i j}(\infty)=m_{i j}(\sigma)+\frac{1}{\sigma} \int_{0}^{\infty} L_{i j}(t) \sin \sigma t d t$

$L_{i j}(t)=\frac{2}{\pi} \int_{0}^{\infty} N_{i j}(\sigma) \cos \sigma d \sigma$

ここに添字 $i 、 j$ は $j$ モード運動による $i$ モード運動 への寄与を表し、 $i 、 j=1 \sim 6$ は運動モード Sway、

Surge、Heave、Pitch、Roll、Yaw である。 $x_{j}(t)$ は 船体動摇の変位または回転角、 $M_{i j}$ は船体の質量また は慣性モーメント、 $m_{i j}(\infty)$ は式 $(7)$ による不変付加 質量または不変付加慣性モーメント、 $L_{i j}$ は式(8)に よるメモリ一影響関数、 $N_{i j}$ は減衰係数、 $D_{i j}$ は粘性 減衰係数、 $C_{i j}$ は静的復原力係数、 $G_{i}$ は非線形係留力 ベクトル、 $F_{i}$ は外力項であり、 $t$ は時刻、 $\sigma$ は角周 波数である。外力項は主に波力 $F_{e i}$ および風圧力 $F_{w i}$ により構成されるが、今回の自由振動時ではゼロと なる。ただし後述するが自由振動における牽引力を 考慮する場合は外力として与える。また防舷材反力 および係留索張力は非線形係留力ベクトルに加味し た。粘性減衰力は Sway、Surge、Ro11、Yawに考慮し た ${ }^{(11)}$ 。なお粘性減衰係数は式(9)に示寸関係がある。

$$
D_{i j}(t)=\frac{4.0 \times a_{i j}}{T_{N i}}\left(M_{i j}+m_{i j}(\infty)\right)
$$

ここに $a_{i j}, T_{N 1}$ は自由振動実験から得られた減滅係 数および固有周期である。添字 $i 、 j$ は $j$ モード運動 による $i$ モード運動への寄与を表すが、当該減衰力 は対角項のみを考慮した。

\subsubsection{Roll 自由振動}

(1) 再現シミュレーションと実験結果の比較

Fig. 13 に実船の船体動摇再現などで使用してい た粘性減滅係数 ${ }^{(3)}$ を用いた Rol1 自由振動の再現シ ミュレーション結果を示す。図中オレンジ色が実験 結果で青色が再現計算結果を示している。実験結果 の方が Rol1 減衰は早く、再現計算では減衰効果が過 小に評価されていることがわかった。

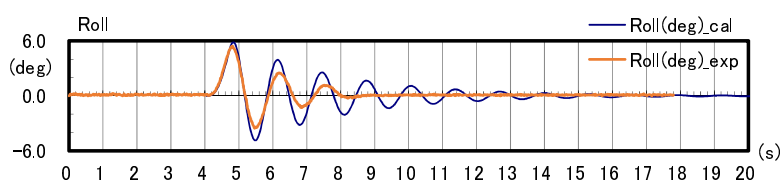

Fig.13 Reproduction on free oscillation in roll using existing extinction coefficient $(\mathrm{av}=0.1)$

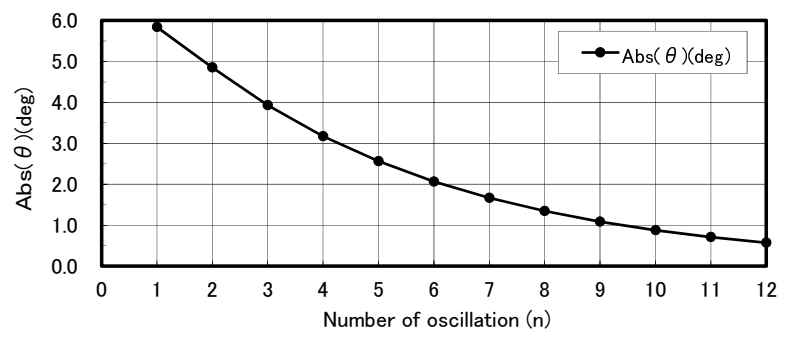

(a) Curve of damping

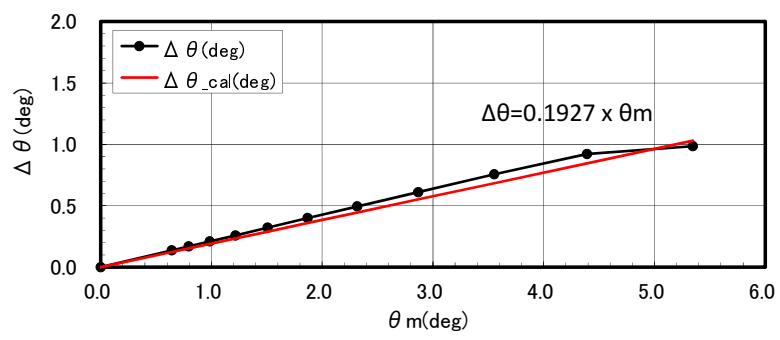

(b) Curve of extinction

Fig.14 Calculation result on curves of damping and extinction in roll of the model ship $(\mathrm{av}=0.1)$

(2) 減滅係数の見直しと再現シミュレーションの 再検討

Fig. 13 再現計算結果について、Fig. 7 と同様に減 衰角曲線および減滅曲線を Fig. 14 に算出した。そし て自由振動結果から得られた減滅係数に対して、設 定した粘性減滅係数および造波減衰力による減滅係 数を式(10)のように分離して Table 3 にまとめる。

$$
a=a_{v}+a_{d} \rightarrow a_{d}=a-a_{v}
$$

ここに $a 、 a_{V}$ および $a_{d}$ は自由振動の再現計算または 実験から得られた減滅係数、設定した粘性減滅係数 および造波減衰力による減滅係数である。

Table 3 において、自由振動再現計算結果の減滅 曲線から算定した減滅係数 (a) が 0.1927 であること および当初設定していた粘性減滅係数 $\left(a_{V}=0.1\right)$ から、 造波減衰力による減滅係数を算出することができる $\left(a_{d}=0.0927\right.$ 。

そこで逆に Rol1 自由振動実験結果から得られた 減滅係数 $(a=0.3749)$ および上記再現計算結果から得 
Table 3 Extinction coefficient in roll during experimental and calculation results

\begin{tabular}{l|c|c|c}
\hline Extinction Co. & $\mathrm{a}$ & $\mathrm{a}_{\mathrm{v}}$ & $\mathrm{ad}$ \\
Free oscillation in Roll & & & \\
\hline Calculation & 0.1927 & 0.1 & 0.0927 \\
\hline Experiment & 0.3749 & 0.2822 & ditto \\
\hline
\end{tabular}

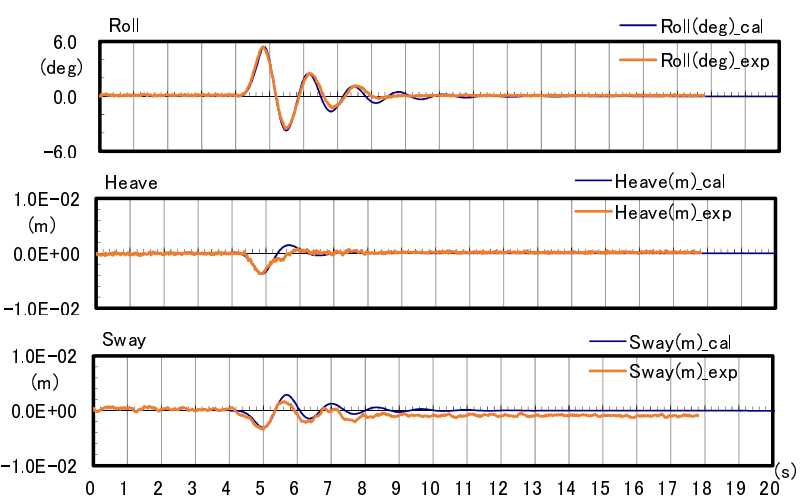

(a) Motions of roll, heave and sway

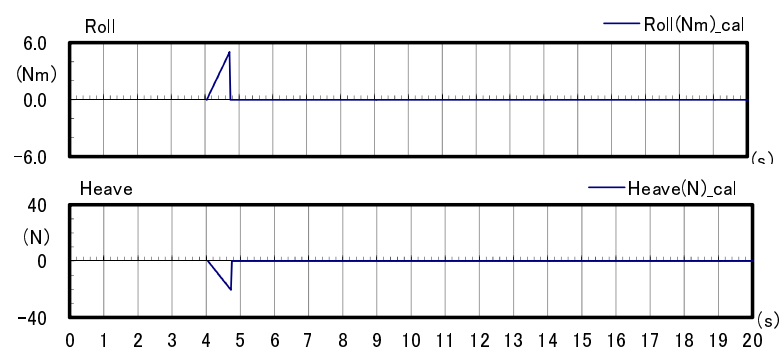

(b) External roll moment and heave force

Fig.15 Reproduction on free oscillation in roll using the extinction coefficient $(\mathrm{av}=0.2822)$

られた造波減衰力による減滅係数 $\left(a_{d}=0.0927\right)$ を用 いて、粘性減滅係数を再評価した $\left(a_{v}=0.2822\right)$ 。そし て改めて当該粘性減滅係数を用いて行なった再現計 算結果が Fig. 15 であるが、実験結果とよく一致する 結果を得た。ここに再現シミュレーションでは、実 験時の Roll 初期傾斜角を与える状況を模して、

Fig. 5 の右舷側上部に鉛直下向きの力を与えて再現 計算を行なった。具体的にはHeave の鉛直下向き最 大変位量とその時刻を参照して、Fig. 15 (b)の Heave 鉛直荷重およびこれに伴う Rol1 モーメントを時系 列的に外力として与えた。これにより Rol1 以外の Heave および Sway についても、実験結果とよく一致 する結果を得た。

\subsubsection{Sway 自由振動}

(1) 初期張力ありの場合

Fig. 8 (a) に示した定反力型防舷材を使用する初
期張力ありの場合の Sway 自由振動実験の再現を試 みる。

Fig. 16 に実船の船体動摇再現などで使用してい た粘性減滅係数 ${ }^{(3)}$ を用いた Sway 自由振動の再現シ ミュレーション結果を示す。図中オレンジ色が実験 結果で青色が再現計算結果を示している。また Table 3 と同様に減滅係数の内訳を Table 4 にまと める。ここに再現シミュレーションでは、実験時の 初期変位を与える状況を模して、Rol1 が発生しない ように Fig. 5 の左右舷側上部を保持して正方向水平 力を与えた。具体的にはSway の正方向最大変位量と その時刻および係留索の初期張力を参照して、 Fig. 16 (b) の Sway 荷重およびこれに伴う Rol1モーメ ントを時系列的に外力として与えた。なお Fig. 16 (b) には再現計算における係留索 L1 の張力お よび防舷材 F1 の反力のみを一例として示している。

Table 4 より自由振動実験から算出された粘性減 滅係数と予め設定していた当該係数が概敉同等であ ったことから、減滅係数の見直しを行わずに実験結 果とよく一致する結果を得た。Sway 以外の Ro11 に ついては、人力で両舷を支持して Sway 変位を与えた ことから、実験ではSway 初期変位を与えるまでは不 安定であるが、人力を解放して模型船が防舷材に接 触する前後では実駼結果とよく一致している。

(2) 初期張力ゼロの場合

Fig. 8 (b) に示した定反力型防舷材を使用寸る初 期張力ゼロの場合の Sway 自由振動実験の再現シミ ュレーション結果をFig. 17 に示す。図中オレンジ色 が実験結果で青色が再現計算結果を示している。合 わせて減滅係数の分離を Table 4 に併記している。

再現シミュレーションでは、同様に Rol1 が発生 しないように Fig. 5 の左右舷側上部を保持して正方 向水平力を与え、Sway の正方向最大変位量とその時 刻、また係留索は柔らかく初期張力がゼロであるこ とを参照して、Fig. 17 (b) に示寸 Sway 荷重のみを時 系列的に外力として与えた。

Table 4 より自由振動実験から算出された粘性減 滅係数と予め設定していた当該減滅係数は概敉同等 であったことから、減滅係数の見直しを行わずに実 験結果とよく一致する結果を得た。Sway 以外の Ro11 については、同様に実験では人力で両舷を支持して Sway 初期変位を与えたことから初期は不安定であ るが、人力を解放して模型船が防舷材に接触する前 後では、実験結果とよく一致する結果を得た。また Table 4 から、造波減衰力による減滅係数 $\left(a_{d}\right)$ は、 


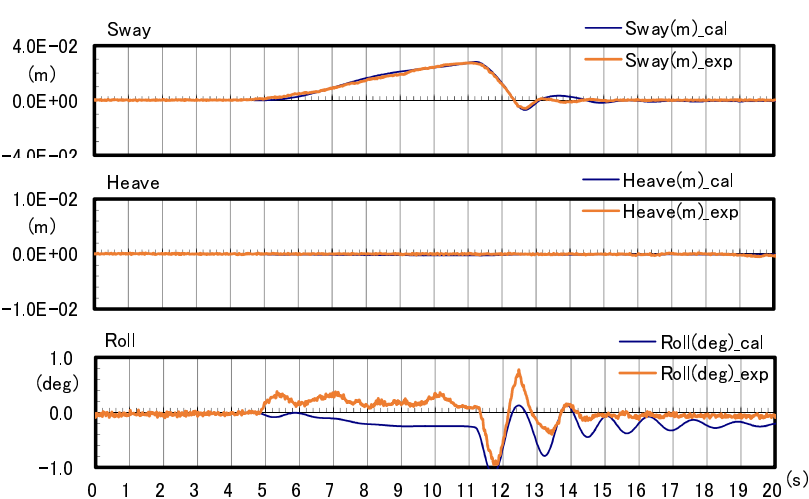

(a) Motions of sway, heave and roll
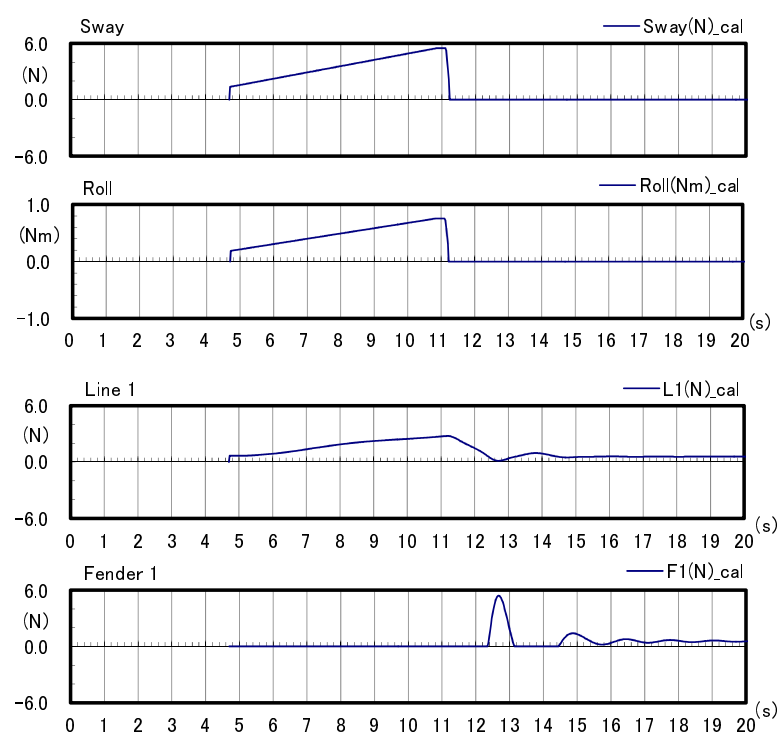

(b) External forces and mooring forces

Fig.16 Reproduction on free oscillation in sway with pretension using the extinction coefficient $(\mathrm{av}=1.0)$

Table 4 Extinction coefficient in sway during experimental and calculation results

\begin{tabular}{l|l|c|c|c}
\hline \multicolumn{2}{r|}{ Extinction Co. } & $\mathrm{a}$ & $\mathrm{a}_{\mathrm{v}}$ & $\mathrm{ad}$ \\
\multicolumn{2}{l}{ Free oscillation in Sway } & & & \\
\hline $\begin{array}{l}\text { with } \\
\text { pretension }\end{array}$ & Calculation & 1.1803 & 1.0 & 0.1803 \\
\cline { 2 - 5 } $\begin{array}{l}\text { without } \\
\text { pretension }\end{array}$ & Experiment & 1.2940 & 1.1137 & ditto \\
\cline { 2 - 5 } & Ealculation & 1.6856 & 1.0 & 0.6856 \\
\hline
\end{tabular}

初期張力ゼロの場合の方が初期張力ありの場合に較 ベて大きく評価されることを実験結果の再現計算を 通して確認できた。つまり初期張力ゼロの場合の方 が、上述の Table 2 に示したように船体運動中にエ ネルギーの散逸を十分に行っていたことが確認され たといえる。

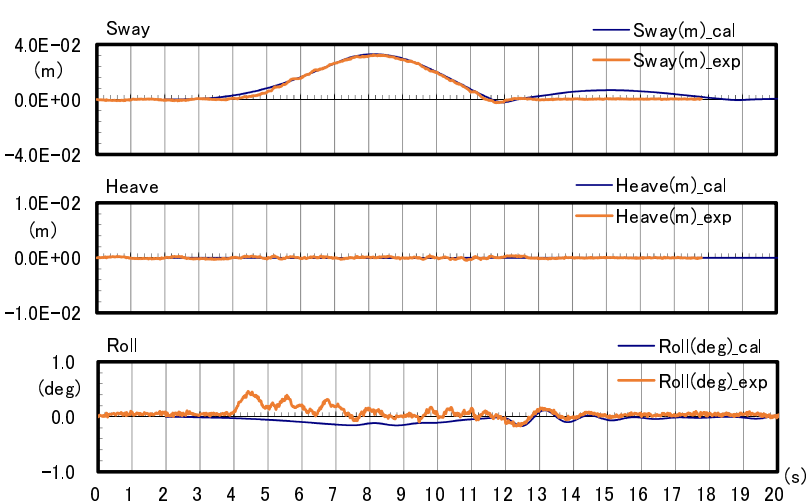

(a) Motions of sway, heave and roll
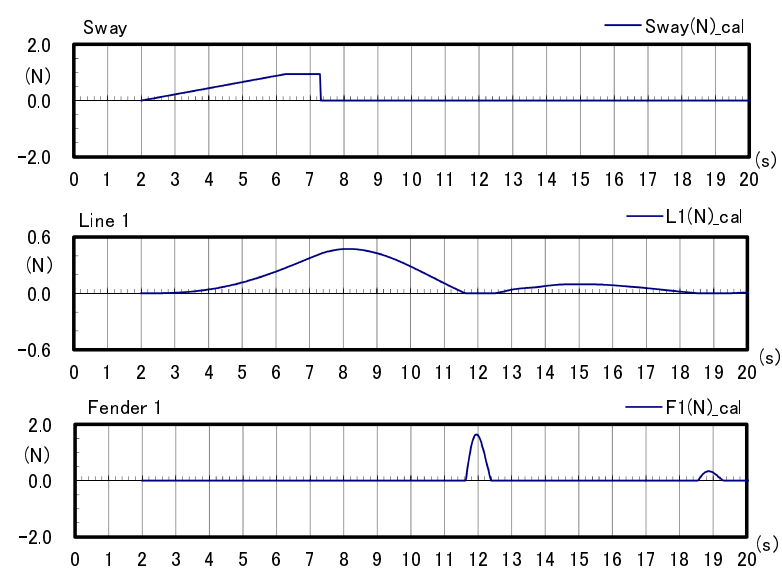

(b) External sway force and mooring forces

Fig.17 Reproduction on free oscillation in sway without pretension using the extinction coefficient $(\mathrm{av}=1.0)$

\subsection{Roll および Sway の固有周期の算定}

\subsection{1 固有周期の算定方法}

Ro11 および Sway の固有周期は式(11)のように求 められる。

$$
\begin{aligned}
& T_{R}=2 \pi \cdot \sqrt{\frac{I_{55}+I_{55}(\infty)}{g \cdot M \cdot G M_{T}}} \\
& T_{S}=2 \pi \cdot \sqrt{\frac{M+m_{11}(\infty)}{g \cdot K L_{S}}}
\end{aligned}
$$

ここに $T_{R} 、 T_{S}$ は Rol1 および Sway の固有周期、 $I_{55}$ $M$ は船体の Rol1 慣性モーメントおよび質量、 $G M_{T}$ は 横メタセンター、 $K L_{S}$ は Sway 方向係留力のバネ定数、 $I_{55}(\infty) 、 m_{11}(\infty)$ は Ro11 の不変付加慣性モーメント およびSway の不変付加質量である。

\subsection{2 固有周期の算定結果}

式(11)に基づき Rol1 および Sway の固有周期を算 
Table 5 Natural periods in sway and roll of the model ship

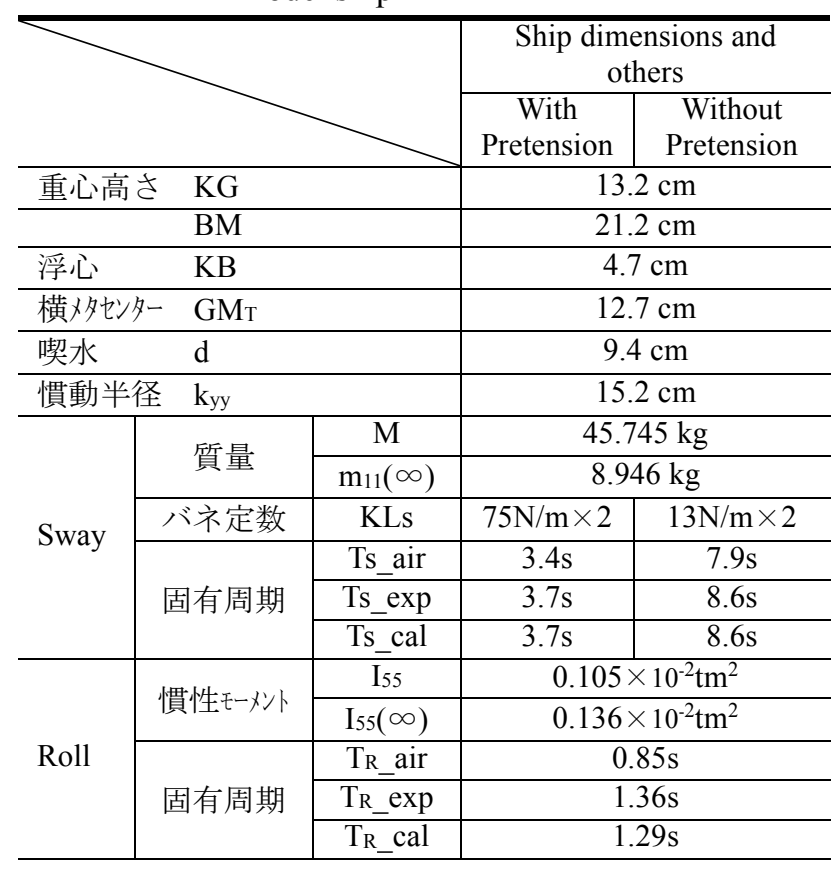

出した結果をTable 5 にまとめる。Table 5 には初 期張力の有無による Sway および Rol1 の固有周期も 併記している。

表中には空中重量を用いる場合 ( T_air ) と実験 結果（T_exp）を示している。実験結果の方が、造波 抵抗力の付加質量（または付加慣性モーメント）の 追加に伴い、長周期化していることが確認された。 また付加質量（または付加慣性モーメント）と復原 力係数（バネ定数または $G M_{T}$ ) を用いて固有周期を 概水算定できることが確認された。

\section{4. 結言}

本研究では大型係留船の固有周期および減衰特 性に関して、実際の大型船の係留状況を設定した模 型船を用いた自由振動実験を行ない、合わせて数值 計算による当該自由振動実験の再現を通じて、固有 周期および減衰特性への係留索の初期張力および防 舷材の特性の影響について検討を行った。得られた 主な結論を要約すると以下のようになる。

(1)Sway の自由振動実験結果において、初期張力あり の場合、Sway の初期変位解放後、係留索の張力に より船体は急速に防舷材側に引き戻されるのに 対して、初期張力ゼロの場合、初期変位解放後、 緩やかに Sway 船体運動が始まり、初期張力あり の場合に較べ、防舷材に接触するまでに時間を要 することがわかった。合わせて船体は防舷材を圧
縮して再び沖側へ離れるが、微小な変位で繰り返 しはほとんど発生しないことが確認された。

(2)Sway の自由振動実験結果において、初期張力あり の場合、船体運動エネルギーは比較的大きな割合 で防舷材に吸収されるのに対して、初期張力ゼロ の場合、防舷材に吸収される船体運動エネルギー は比較的小さくなり、造波減衰力などその他の工 ネルギーとして消費される割合が大きいことが わかった。

(3)Sway の自由振動実験結果において、空気式防舷材 (柔らかいバネ) の場合、防舷材の圧縮変位が大 きく緩やかで、かつ船体の防舷材一の接岸後の沖 側への戻りもゆっくりとなることが確認された。 このことから定反力型防舷材（硬いバネ）の場合 に較べ、防舷材が負担する船体の接岸エネルギー の割合が比較的低減され、造波減衰力などその他 のエネルギーとして消費される割合が大きくな ることがわかった。

(4)式 (9) に示す粘性減衰力の付加による自由振動の 再現において、実船の船体動摇再現などで使用し ていた Sway 粘性減滅係数については模型実験と よく一致する結果を得たが、Ro11については、模 型船が矩形船であることもあり、模型実験での係 数の方が大きく評価された。また Sway 粘性減滅 係数が初期張力ありの場合とゼロの場合で概ね 同じ值をとり、一方造波減衰力による Sway 減滅 係数は初期張力ゼロの場合の方が初期張力あり の場合に較べて大きくなることを模型実験と再 現計算を通して確認できた。

(5)Sway およびRo11 の自由振動実験結果の再現計算 において、予め不変付加質量および不変付加慣性 モーメントを別途数值計算で求めると共に、造波 減衰力以外の係留索のヒステリシスロスや非線 形流体力に起因する粘性減衰力についても自由 振動実験から適切に設定・評価する必要性のある ことがわかった。

(6)Sway および Rol1 の固有周期算定において、予め 不変付加質量および不変付加慣性モーメントを 別途数值計算で求めると共に、復原力係数 (バネ 定数または $\left.G M_{T}\right)$ を適切に設定することにより固 有周期を概ね算定できることが確認された。

今後も模型実験による定量的検討も加えて、外洋 に面する港湾における船舶係留の安全性向上および 対策に関する研究を進めたく考えている。 


\section{参考文献}

（1）久保雅義：港内係留船の動摇とその制御, 水工 学シリーズ, 87-B-2, 土木学会水理委員会, 1987.

（2）（財）沿岸技術研究センター：港内長周期波影 響評価マニュアル， No. 21， 2004.

（3）榊原繁樹 - 久保雅義：大型鉱石船が荷役中に遭 遇した気象・海象条件と船体運動の相関に関寸 る調查研究, 日本航海学会論文集, 第 133 号, pp. 1-11， 2016.

（4）久保ら：岸壁前面係留浮体の不規則波による船 体運動の時系列解析について, 海岸工学論文集, 第 35 巻, pp. 687-691, 1988.

（5）白石ら：数值シミュレーションによる係留船舶 の長周期動摇の評価に関する考察, 海洋開発論 文集, 第 18 巻, pp. 137-142, 2002.

（6）大塚ら：係留小型船舶の動摇現象解明に関寸る 研究, 寒冷沿岸域チーム, 2009.

（7）久保ら：長周期船体運動計測装置の試作と計測 結果について, 神戸商船大学紀要, 第 28 巻, pp. 289-298, 1980.

（8）藤畑ら：船体動摇計算における港内副振動の考 慮方法と粘性減衰係数の評価, 海岸工学論文集, 第 46 巻, pp. 856-860, 1999.

（9）株式会社ライブラリー：リアルタイムトラッカ 一Radish/3D、3 次元動画計測ソフトゥエア Move-tr/3D.

（10）元良誠三監修: 船体と海洋構造物の運動学, 成 山堂（改訂版）, p. 80, 1997.

（11）榊原繁樹・阿部郁男 - 津金正典・久保雅義 : 東 北地方太平洋沖地震津波来襲時の係留 VLCC の 挙動再現について, 日本航海学会論文集, 第 127 号, pp. 57-68, 2012. 